\title{
Adhocracy Culture Support and Leader's Working Creativity
}

\author{
Aan Khurosani
}

\begin{abstract}
The aim of this study is to investigate the relationship between adhocracy culture support and working creativity belong to the leader, through the strength of cohesive freedom value and learning commitment. Samples in this study are the owner and manager of distribution outlet in Bandung, Western Java province of Indonesia. The sizes of the samples are 226 respondents. This study uses Software AMOS program to overcome any problems that may emerge in structural application equation model. The result of this study states that there is positive and significant relationship between adhocracy culture support and the strength of cohesive freedom value, there is positive and significant relationship between the strength of cohesive freedom value and learning commitment, there is positive and significant relationship between the strength of cohesive freedom value and leader's working creativity, and there is positive relationship between learning commitment and leader's working creativity.
\end{abstract}

Index Terms-Adhocracy culture support, the strength of cohesive freedom value, learning commitment, and creativity.

\section{INTRODUCTION}

In creative industries, creativity becomes the most important factor to be owned by the owner or manager. There are a lot of creative industries that lost in their competition since their lack of creativity. Being innovated through creativity becomes the most important factor in reaching success and competitive advantage in an organization [1]. An organization, especially the one with sophistic technology support, must be more creative and more innovative than another organization, to keep their survival, growth and leadership [2], [3].

Quality and innovation in an organization are closely related with organizational culture. Organizational culture is the key variable which is able to push the company's success. Though it is not completely true, but an organization which is successful is an organization that has a strong culture which is suitable with its environment [5], [6]. Adhocracy culture is a culture that able to environment adapt. Adhocracy culture is an organizational culture that will provide a larger opportunity for its individual to develop their specific own way, on one condition that the way is consistent with the aim of an organization [7]. The focus of an organization is to get as many as opportunity from its external environment. A person will be considered as a successful people if they can create and develop new ideas and new innovation [8].

Nevertheless, in previous study, the relationship between culture or organizational climate and creativity or innovation

Manuscript received April 4, 2013; revised June 4, 2013.

Aan Khurosani is with Sultan Ageng Tirtayasa University, Banten-Indonesia (e-mail: aankhurosani@gmail.com). is still relatively limited [9]. Therefore, it needs strength of culture values that will provide a cohesive freedom to any individual to express themselves in delivering their creativity in their performance. Next, to provide a support to individual's creativity value, it needs a continuous learning process with a high learning commitment. Organizational learning is an aspect that consists of a willingness to learn, mind openness, simultaneous vision and knowledge sharing [10]. In creative industry contextual, cohesive freedom value is a behavior that has a freedom of express which is based on the strength of group cooperation, in order to push the working creativity improvement. This study explicitly observes the relationship between adhocracy culture supports on leader's working creativity through cohesive freedom value and learning commitment in Distribution Outlet (Distro) in Bandung, Western Java province of Indonesia. Distro is one of the creative industrious in Indonesia.

\section{LITERARY REVIEW AND HYPOTHESES DEVELOPMENT}

\section{A. The Relationship between Adhocracy Culture and the Strength of Cohesive Freedom Value}

Adhocracy culture, also called as entrepreneurial culture and development combine with a focus on high flexibility level that highlights in competitive position; it is an organizational culture which is supported by an open system that promotes a willingness to have an action [5], [11].

The purpose of adhocracy culture is to push the adaptability, flexibility and creativity [11]. This kind of adhocracy culture is marked with an ability to be dynamic and innovative. Adhocracy culture also supports the freedom to take any initiative as the source of competitive advantage [12]. Adhocracy also shows its superiority in its performance on different products and environment. Dynamic and innovative working environment will support a leader to be creative and dare to take any risk (risk acceptance).

Every organization which is based on its tough value, enduring principles, will show what is considered to be the main factor for the organization [13]. Organization value is the realized assumptions which is tightly held and becomes the belief in the heart of organizational culture. It will direct all decision made in every level in an organization [14]. Without organization values, the member of this organization will follow their own value in a different way with organization's way, in which these values originated from their own culture and experience [15]. These values are closely related and support one another [16], until every member of an organization share the common perception of organization's value.

Every organization has one aim to enlarge their new 
product to reach the quick growth, and its success will be determined by their ability to produce unique products and relevant new services. With adhocracy culture support these values will be harmoniously united with membership principles and external orientation. Adhocracy culture is focused in creativity, adaptation dynamic and external indication response [17]. Based on these arguments above, it can be concluded hypothesis as follow:

- H1: There is a positive relationship between adhocracy culture support and the strength of cohesive freedom value.

\section{B. The Relationship between the Strength of Cohesive Freedom Value and Learning Commitment}

Literature on the strength of cohesive freedom value in this study is to bridge the gap between organization cultures and working creativity. The strength of cohesive freedom value is a behavior that expresses creativity freedom which is based on the strength of group cooperation. The strength of this value will push the improvement of working creativity.

In an organization, value is the indication of a certain characteristic that will determine the success of an organization [18]. It becomes a belief and inner attitude of an organization, it is also a collectively comprehension on the accepted norms and standard in organization's behavior. It means that these values are considered as the most important component of an organization culture [19], [20].

Organizational culture and commitment has tight relationship. Norms, symbols, values, belief and the base of assumption commitment are shaped in here. Culture is also viewed as a control mechanism to make an organization commitment [21]. Organization which has stronger and richer culture will have more committed and more loyal employees [22].

The strength of cohesive freedom value is a part of an organizational culture that has a role to improve learning commitment in creative industry. The role of cohesive freedom value is to facilitate the formation of an organizational culture in learning and changing process [23]. Organizational culture learning becomes the important factor in innovative consideration since it enables an organization to anticipate and adapt with any environment change. As a matter of fact, organizational culture learning is marked as a willingness of each member in an organization to study and respect the high performance in the application of progressive learning and innovative working [24], [25]. Based on these arguments, it can be concluded hypothesis as follow:

- H2: There is a positive relationship between the strength of cohesive freedom value and learning commitment.

\section{The Relationship between the Strength of Cohesive Freedom Value and Leadership Creativity}

In a rapid dynamic speed, an organization and its leader must keep their surviving effort to create a strong organization in which creativity and innovation will be accepted as a based norm. Unwritten rule (behavior norms) and many values will influence the spirit, performance and creativity application and innovation in many different ways
[26]. Values, norms and assumptions will involve themselves in promoting and performing creativity and innovation [27]-[30].

Creating creative climate in an organization is truly needed, since it will enable any efforts build an organizational culture that enables any individual in the organization to perform an innovation. One of the main keys to raise the creativity in a group is the freedom.

The strength of cohesive freedom value will be a way to improve the working creativity. The freedom value will ease a leader to compose creative ideas. Based on these arguments above it can be concluded a hypotheses as follow:

- H3: There is a positive relationship between the strength of cohesive freedom value and leader's working creativity.

\section{The Relationship between Learning Commitment and Leader's Working Creativity}

Learning is called as an experience to raise any permanent changes in knowledge, skill or behavior, whereas training involves any systematical efforts to help learning through instruction [31]. Learning becomes the main element of creativity [32]. According to social cognitive theory [33], an individual will get knowledge and skill through their experience in finishing any tasks and trainings, to help creating role model. Learning commitment focuses in the values that are based in learning activity in an organization, and these values are viewed as an organization's axiom [34]. This study shows that organizational learning is a part of external learning which motivates an individual to develop their own competence. Learning orientation as a part of impelling power to support individual to search any challenges, have a future vision, learn from any opportunity and to get a new knowledge and skill, which all will help improving their creativity [35]-[37]. Based on the arguments above, it can be concluded the hypothesis as follow:

- H4: There is a positive relationship between learning commitment and leader's working creativity.

To get a clear description based on these four constructs, it can be seen from theoretical model below (Fig. 1):

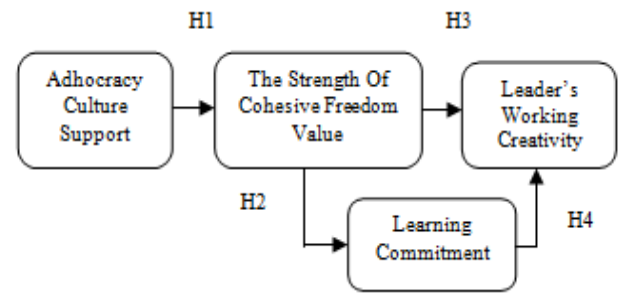

Fig. 1. Theoretical model

\section{METHOD}

This study uses distributed questionnaires as a survey instrument in every Distribution Outlet in Bandung, Western Java Province of Indonesia. There are 230 distribution outlets as sample in this study. The sample size has met the criteria as 3 years operational experience in distribution outlet. Sample consist of 165 male (72\%) and 65 female (28\%). 44 respondents graduated from Senior High School (19\%), 184 
respondents from S1 program (80\%), and 2 respondents graduated from Master program (1\%).

In making valid and reliable questionnaire, some items are composed based on related literature from the previous studies. The questionnaires consist of two main parts. The first part is about the demography of the sample, and the other part is about adhocracy culture support, the strength of cohesive freedom value, learning commitment and leader's working creativity. Indicators that are used in adhocracy culture support consist of 6 items adopted from [7]. Respondents are asked to measure on (acs1) the support in adaptation, (acs2) flexibility, (acs3) the support in innovation, (acs4) the support to create new standard, (acs5) continuous renewal, (acs6) being creative in searching any solution. Indicators that are used to measure the strength of cohesive freedom value are adapted from [13], [16], [38], [39] and consist of (scfv1) having a strong belief, (scfv2) having the authority, (scfv3) having a freedom to be creatively judgment, (scfv4) closed communication flow with the inferior, (scfv5) the emergence of group's new ideas. Learning commitment indicators are adapted from [31], [40]-[43] and consist of (lc1) willingness to study, (lc2) willingness to follow the training, (lc3) doing reformation, (lc4) the new suggestion openness, (lc5) performing comparative study. Meanwhile indicators that are used to measure the leader's working creativity are adapted from [44]-[46]. Indicators to measure leader's working creativity are measured with (lwc1) the ability to produce new ideas, (lwc2) the ability to have imaginative thought, (lwc3) the ability to change the way of working, (lwc4) the ability to combine new ideas, (lwc5) the ability to solve the problems. Each questionnaire is measured with 10 scale of measurement, where 1 shows the opinion as "absolutely disagree" and 10 shows the opinion as "absolutely agree". The study uses data analyses by using Software AMOS 18 Program. AMOS program is a tool to solve Structural Equation Modeling problems which is based in covariance matrix as input data to the entire estimation [47].

\section{RESUlt AND DisCUSSION}

\section{A. Statistic Descriptive}

Distributed questionnaires are 230. Of the distributed questionnaires, there are 4 questionnaires which are filled and returned to the authors with response rate as $1.9 \%$. There are 226 questionnaires which are returned with response rate as $98.1 \%$. Therefore, data in this study to further analysis was 226 questionnaires. Respondents in this study are the owner, manager and both manager and the owner of Distribution Outlet in Bandung, Western Java Province of Indonesia. Of the returned questionnaires, respondents that become the owner ad also the manager are 126 people (56\%), the managers are 64 persons $(28 \%)$ and the owners are 36 people $(16 \%)$

\section{B. Data Quality Testing}

Table I shows goodness of fit index value for all used criteria from Chi-square, probability, RMSEA, GFI, AGFI, CMIN, CFI, TLI testing. Based on the testing result it can be concluded that the model is adequately used to test the hypotheses and it has value in required range.

TABLE I: TESTING RESULTS

\begin{tabular}{|l|c|c|c|}
\hline $\begin{array}{c}\text { Goodness-of-fit- } \\
\text { index }\end{array}$ & Cut-off- value & Result & Information \\
\hline Chi-Square & 93,94 & 50,157 & \multicolumn{2}{c|}{$\begin{array}{c}\text { Chi-Square Fit }< \\
\text { Chi } \begin{array}{r}\text { Square } \\
\text { Tabel, df }=40\end{array}\end{array}$} \\
\hline Probability & $\geq 0,05$ & 0,130 & Fit \\
\hline RMSEA & $\leq 0,08$ & 0,035 & Fit \\
\hline GFI & $\geq 0,90$ & 0,959 & Fit \\
\hline AGFI & $\geq 0,90$ & 0,933 & Fit \\
\hline CMIN/DF & $\leq 2,00$ & 1,254 & Fit \\
\hline TLI & $\geq 0,95$ & 0,960 & Fit \\
\hline CFI & $\geq 0,95$ & 0,971 & Fit \\
\hline PNFI & $\geq 0,5$ & 0,636 & Fit \\
\hline PCFI & $\geq 0,5$ & 0,706 & Fit \\
\hline
\end{tabular}

\section{Hypotheses Testing}

To test the proposed hypotheses, we can see it from the result of t-statistic testing, in which there is a limitation to accept or deny the proposed hypotheses from t-table testing at \pm 1.96 . If $\quad \mathrm{t}$-statistic value is in the range between -1.96 and 1.96, the proposed hypothesis will be denied. Meanwhile if t-statistic value is higher than t-table value, at 1.96, the proposed hypotheses will be accepted. Estimation result from t-statistic value can be seen at Table II. Based on the result in Table II, all hypotheses are accepted, where the value of CR $>$ 1.96 and the probability value $(\mathrm{p}<0.05)$.

TABLE II: REGRESSION WEIGHTS

\begin{tabular}{|lll|rrrr|}
\hline & & & & & & \\
& & & Estimate & S.E. & C.R & P \\
& & & & &. & \\
\hline SCFV & $<--$ & ACS & .848 & .164 & 5.157 & $* * *$ \\
LC & $<--$ & SCFV & 1.138 & .297 & 3.835 & $* * *$ \\
LWC & $<--$ & SCFV & .417 & .121 & 3.443 & $* * *$ \\
LWC & $<--$ & LC & .134 & .055 & 2.454 & .014 \\
\hline
\end{tabular}

\section{Discussion}

The first result of this study states that there is a positive and significant relationship between adhocracy culture support and the strength of cohesive freedom value $\left(5.157>1.96, \mathrm{p}^{* * *}\right)$. Adhocracy culture support which is suitably used in this study is the flexible working schedule, the improvement of continuous working system and being creative in searching solution. Working flexibility in fashion distribution outlet as creative industry will be applied by the leader. Working flexibility will make their employee free from any pressure; it will finally yield a freedom to produce new ideas. This kind of flexibility will make the employee to be more motivated in keep searching new ideas. In addition, a successful company will always improve their working system. The improvement of working system will push the employees to be initiative in creating new and creative solution.

The second result of this study states that there is a positive and significant relationship between the strength of cohesive freedom value and learning commitment $\left(3.835>1.96, \mathrm{p}^{* * *}\right)$. Individual will be able to produce new and more creative ideas, when their freedom of thought is not limited. The strength of cohesive freedom value is based on the power of 
cooperation between working group to share knowledge and ideas. The result of this cooperation will produce new and more creative ideas. The ability to produce creative newer ideas will be attained when these individual have the willingness to learn. Through learning process, the information exchange will happen and they will get more creative application ideas.

The third result of this study states that there is a positive and significant relationship between cohesive freedom value and leader's working creativity $\left(3.443>1.96, \mathrm{p}^{* * *}\right)$. In an organization that applies freedom culture of thought, there will also a raise of creative suggestion and ideas. The strength of cohesive freedom value in performing task and the freedom of creative thinking will yield working creativity. The gap in this study with the previous studies is highlighted on the relationship between organizational culture and creativity / innovation [9], and this gap will be bridged by the strength of cohesive freedom value by giving a freedom and belief in creative thinking.

The fourth result in this study states that there is a positive relationship between learning commitment and leader's working creativity $(2.454>1.96, \quad \mathrm{p}<0.014)$. In global competition, a company that will be able to compete with the leading company is the companies that always study. Learning commitment from the leading company is a must. The awareness from the leader to study will emerge the permanent change in knowledge, skill, and behavior. The study shows that learning will motivate an individual to develop their own competence. Learning commitment will push any individual to search any challenges, have a future vision, so as they will be able to grow and develop, get a new knowledge and skill, that all will help improving their working creativity. Based on line analyses, the result from this study shows that that the first relationship between adhocracy culture support and leader's working creativity through the strength of cohesive freedom value will have value as 0.54 , whereas the second result from the relationship between adhocracy culture support and leader's working creativity through the strength of cohesive freedom value will and learning commitment will have value as 0.20 .

\section{CONCLUSION, IMPLICATION AND LIMITATION}

The present study explains the importance of adhocracy culture support to improve working creativity through the strength of cohesive freedom value and learning commitment The result from this study shows that there is a positive relationship between adhocracy culture support and the strength of cohesive freedom value. The result from this study is in line with the result from previous studies which stated that adhocracy culture support will push the freedom and initiatives as source in creating competitive advantage for an organization.

The second result of the study finds out that there is a positive and significant relationship between the strength of cohesive freedom value and learning commitment. To improve the working creativity, the freedom value will push an individual to make them more committed in learning. The role of the strength of cohesive freedom value will be used as a facilitator in learning and changing process.
The third result of the study states that there is a positive and significant relationship between the strength of cohesive freedom value and working creativity. The strength of cohesive freedom value is the freedom that belongs to any individual since they will be given a belief from their superior to be free in creating new ideas.

The fourth result of this study states that there is a positive relationship between learning commitment and leaders' working creativity. It means that leader's working creativity will be facilitated by learning commitment. Learning commitment will push any individual in searching any challenges; get a new knowledge and skill, in order to improve their working creativity.

Based on the result analyses, it shows that adhocracy culture support on leader's working creativity through the strength of cohesive freedom value will provide greater influence compared with adhocracy culture support on leader's working creativity through the strength of cohesive freedom value and learning commitment. In other words, leader's working creativity will be better if it is directly supported with adhocracy culture support and the strength of cohesive freedom value.

Theoretically, the result from this study is expected to provide a clear explanation for the academician, in how to solve any ambiguity in the previous studies, and the result from this study is expected to be a reference in human resources management, especially in discussing the organizational culture, adhocracy culture, the strength of cohesive freedom value, learning commitment and working creativity.

Practically, the result from this study is expected to be a reference for the owner and manager of distribution outlet in developing and improving their working creativity by adhocracy culture support, the strength of cohesive freedom value and learning commitment.

This study also has some drawbacks, such as the limited sample size area that only performs in Bandung, Western Java Province.

The second limitation of this study is the limited focus on Distribution Outlet Sector without considering other sectors, such as advertising, art and antique craft market, film, video, and photography, music, publishing, computer software and hardware market, radio and television.

The third limitation of this study is that this study only measures the leader's working creativity and it does not measure the leader's performance.

\section{ACKNOWLEDGMENT}

I would like to acknowledge and extend my heartfelt gratitude to Prof. Dr. Miyasto, SU, Prof. Augusty Ferdinand, DBA, Ibn Widiyanto, Ph.D., Dr. Indi Djastuti, MS, my colleagues at Sultan Ageng Tirtayasa University whose help, stimulating suggestions, knowledge, experience and encouragement helped me in finishing this paper. I would also like to thank to my wife, Engkun Kurniasih, and our 
children Devada Kellya Fasha and Muhammad Arya Mandalika for their support and encouragement.

\section{REFERENCES}

[1] R. W. Woodman, J. E. Sawyer, and R. W. Griffin, "Toward a theory of organizational creativity," Academy of Management Review, vol. 18 pp. 293-321, 1993.

[2] D. I. Jung, C. Chow, and A. Wu, "The role of transformational leadership in enhancing organizational innovation: hypotheses and some preliminary findings," The Leadership Quarterly, vol. 14, pp. 525-544, 2003.

[3] P. Tierney, S. M. Farmer, and G. B. Graen, "An examination of leadership and employee creativity: the relevance of traits and relationships," Personnel Psychology, vol. 52, pp. 591-620, 1999.

[4] J. L. Michela and W. W. Burke, "Organizational culture and climate in transformations for quality and innovation," in N.M. Ashkanasy, C.P.P. Wilderom \& M.F. Peterson (Eds.), Handbook of organizational culture and climate, California: Sage, 2000

[5] D. R. Denison, "Corporate Culture and Organizational Effectiveness," Administrative Science Quarterly, vol. 29, pp. 52-73, 1990.

[6] J. Kotter and J. Heskett, Corporate culture and performance, New York: Free Press, 1992

[7] K. S. Cameron and R. E. Quinn, Diagnosing and changing organizational culture: Based on the competing values framework, Reading, MA: Addison Wesley, 1999.

[8] E. Aktas, C. Isik, and K. Mithat, "The effect of organizational culture on organizational efficiency: the moderating role of organizational environment and CEO values," Procedia Social and Behavioral Sciences, vol. 24, pp. 1560-1573, 2011.

[9] L. D. McLean, "Organizational culture's influence on creativity and innovation," A review of the literature and implications for human resource development advances in developing human resources, vol. 7 , no. 2, pp. 226-246, May 2005.

[10] C. J. Roger, S. T. Cavusgil, and Y. Zhao, "Learning orientation, firm innovation capability, and firm performance," Industrial Marketing Management, vol. 31, no. 6, pp. 515. 2002.

[11] K. S. Cameron and R. E. Quinn, Diagnosing and changing organizational culture, Revised Edition, San Francisco: The Jossey-Bass, 2006.

[12] R. Deshpande and J. U. Farley, "Corporate culture and market orientation: Comparing Indian and Japanese firms," Journal of International Marketing, vol. 7, no. 4, pp. 111-127, 1999.

[13] J. C. Collins and J. I. Porras, "Building your company's vision," Harvard Business Review September-October, pp. 65-77, 1996.

[14] A. Howell and A. Kirk-Brown, "This goes with that . . which value sets maximize organizational commitment," in Proceedings of the 5th Annual Hawaii International Conference on Business, Honolulu, HI, USA, May, 2005

[15] M. Rokeach, The Nature of Human Values, the Free Press, New York, 1973.

[16] P. McDonald and J. Gandz, "Getting value from shared values," Organizational Dynamics, pp. 64-77, 1992.

[17] H. J. Irtaimeh, "Transformational leadership and adhocracy culture in ZAIN cellular communications company operating in Jordan," European Journal of Economics, Finance and Administrative Sciences, ISSN 1450-2275, no. 37, 2011.

[18] R. M. Williams, "Change and stability in values systems: a sociological perspective," in Rokeach, M. (Ed.), Understanding Human Values, The Free Press, New York, NY, pp. 15-46, 1979.

[19] J. B. P. Sinha, "The culture context of leadership and power, sage international," New Delhi, 1995.

[20] M. J. Hatch, "The dynamics of organizational culture," Academy of Management Review, vol. 18, no. 4, pp. 657-93, 1993.

[21] S. A. Sackmann, Culture Knowledge in Organization: Exploring the Collective mind, Newbury Park, CA: Sage Publications, 1991

[22] K. S. Cameron, S. Kim, and D. R. Ettington, "The conceptual foundations of organizational culture, higher education," Handbook of Theory and Research, New York: Agathon, 1988.

[23] A. C. Bluedorn and E. F. Lundgren, "A culture-match perspective for strategic change," Research in Organizational Change and Development, vol. 7, pp. 7-9, 1993.

[24] J. B. Tracey, S. I. Tannenbaum, and M. J. Kavanagh, “Applying trained skills to the job: The importance of the work environment," Journal of Applied Psychology, vol. 80, no. 2, pp. 239-52, 1995.

[25] J. M. Rosow and R. Zager, "Training: the competitive edge," San Francisco, CA: Jossey-Bass, 1988.
[26] E. Martins and R. Martins, "An organizational culture model to promote creativity and innovation," SA Journal of Industrial Psychology, vol. 4, no. 28, pp. 58-65, 2002.

[27] P. K. Ahmed, "Culture and climate for innovation," European Journal of Innovation Management, vol. 1, no.1, pp. 30-43, 1998.

[28] W. Q. Judge, G. E. Fryxell, and R. S. Dooley, "The new task of R \& D management: creating goal-directed communities for innovation," California Management Review, vol. 39, no. 3, pp. 72-85, 1997.

[29] C. O'Reilly, "Corporation, culture, and commitment: motivation and social control in organizations," California Management Review, vol. 9, pp. 10-25, 1989.

[30] P. E. Tesluk, J. L. Faar, and S. R. Klein, "Influences of organizational culture and climate on individual creativity," The Journal of Creative Behavior, vol. 31, no. 1, pp. 21-41, 1997.

[31] A. Johnson, H. Hong, M. Groth, and S. K. Parker, "Learning and development: promoting nurses' performance and work attitudes," Journal of Advanced Nursing, vol. 67, no. 3, pp. 609-620, 2011.

[32] R. W. Weisberg, "Creativity and knowledge: A challenge to theories," in R. J. Sterngerg (Ed.), Handbook of creativity, New York: Cambridge University Press, pp. 226-250, 1999.

[33] A. Bandura, Social foundations of thought and action: A social cognitive theory, Englewood Cliffs, NJ: Prentice-Hall, 1986.

[34] P. Senge, The fifth discipline: the art and practice of the learning organization, Doubleday, New York, NY. 1990.

[35] T. M. Amabile, "A model of creativity and innovations in organizations," in B. M. Staw \& L. L. Cummings (Eds.), Research in organizational behavior, Greenwich, CT: JAI Press, vol. 10, pp. 123-167, 1990.

[36] Y. Gong, J. Huang, and J. Farh, "Employee learning orientation, transformational leadership, and employee creativity: The mediating role of employee creative self-efficacy," Academy of Management Journal, vol. 52, pp. 765-778, 2009.

[37] D. V. Walle, W. L. Cron, and J. W. Slocum, "The role of goal orientation following performance feedback," Journal of Applied Psychology, vol. 86, pp. 629-640, 2001.

[38] J. B. Barney, "Organizational culture: can it be a source of sustained competitive advantage?" Journal of Academy Management Review, vol. 11 , no. 3 , pp. 656-665, 1986.

[39] E. H. Schein, Organizational Culture and Leadership, San Francisco, Jossey-Bass, 2004

[40] F. T. Mavondo, J. Chimhanzi, and J. Stewart, "Learning orientation and market orientation," European Journal of Marketing, vol. 39, no. 11/12, pp. 1235-1263, 2005.

[41] E. C. Nevis, A. J. DiBella, and J. M. Gould, "Understanding organizations as learning systems," Sloan Management Review, vol. 36, no. 2 , pp. 73-85, 1995 .

[42] P. A. Shrivastava, "Typology of organizational learning systems," Journal of Management Studies, vol. 20, pp. 7-29, 1983.

[43] T. G. Habbershon, M. L. Williams, and MacMallan, “A unified systems perspective of family firm performance," Journal of Business Venturing, vol. 18, no. 4, pp. 451-465, 2003.

[44] S. G. Harris and K. W. Mossholder, "The affective implications of perceived congruence with culture dimensions during organizational transformation," Journal of Management, vol. 22, no. 4, 1996.

[45] T. M. Amabile, "The social psychology of creativity: A componential conceptualization," Journal of Personality and Social Psychology, vol. 45 , pp. $357-376,1983$

[46] S. F. Kylen and A. B. Shani, "Triggering creativity in teams: an exploratory investigation," Creativity and Innovation Management USA, MA: Blackwell Publishers Ltd., vol. 11, no. 1, pp. 17-30, 2002.

[47] A. Ferdinand, Structural Equation Modeling Dalam Penelitian Manajemen, Penerbit Universitas Diponegoro, Semarang, 2006.

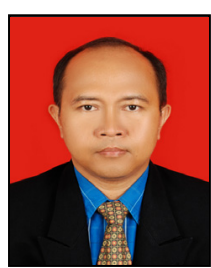

Aan Khurosani was born in Serang, Banten, on 04 February 1970. He earned a master's degree in management in 2004 from the College of Management IMMI Jakarta - Indonesia. He currently studies in the doctoral program in Management economics at Diponogoro University, Semarang, Indonesia. He is a lecturer in Management Department, Economic Faculty, Sultan Ageng Tirtayasa University, Banten-Indonesia. Current research on adhocracy culture support and Leader's Working Creativity 